\title{
CONTINGENCY OF AN ARCHITECTURAL CRITICAL APPROACH
}

\author{
A B S T R A C T
}

Contemporariness of architecture can be interpreted in diverse ways. Starting from a basically formulated modern context, which is even nowadays understood as such, in which the limits of stability of the architectural profession are examined, our concern is the designer's intention to research within a wider cultural context. We are actually considering the capacities of the profession for continuous development of its own critical apparatus. Through the question of the relation between the general and the individual, followed by the question of integrity and proportion of architectural effect, but also by the role of media and digitalization of the world, in the focus of this text projected are the scenes of reality filled with the values of architecture willing to develop, within itself, the analytical and synthetic concepts relying on the contextual, but also on the own indetermination and instability regarding the concept of the space and time. 


\section{CONTEMPORARINESS}

Modernity has always presented readiness for the new, a principle changeability or metaphor which confirmed that it was possible to keep pace with time. Even though being aware that each advance could be unguarded for the profession existing already for thousands of years in the almost unchanged structure of its inner relations, if we accept it is possible to see the changeability of architecture as part of its contemporary frame, the real weight of the professional legacy can only be 'distributed' by expanding its spatial-time context. Still strong presence of the notion of modernity can be explained by isolated architectural debates in the registry of the Scruton-ian romantic conservatism which has its stronghold in 'excessive' stability of the profession, the idealized past and (great) expectations from the future. Such starting point is of significance for architecture since with it the safety in the concept of reality ${ }^{1}$ is made possible, which, yet, starting exactly from Scruton, is not only the architectural one.

Civilization dispersion, as the result of globalization, first emerged within the fields which tangent architecture, and thereafter also architecture itself became a part of tat universal process. Contemporariness cannot be comprehended per se. For Robert Maxwell, even though it is a question style of centrally positioned modernity in the first place, it concerns the permit to change in respect to changeability and stability ${ }^{2}$ found in the analogy of the sequence of the past (stability), the present (change) and the future (stability). In that respect the past can be seen within the context of the theoretical constructions which are in a way idealized, the future as the breakthrough toward the other ways of life, whereas the present stretches between the changes and stability in the span of its own necessities and beliefs.

\section{REALITY OF OBJECTIVE}

According to Nicolas Bourriaud the reflections of reality occur in the fight of one image versus the other image analyzing the contemporariness as experience of the real through fiction. ${ }^{3}$ That which is vital for such perception of the relational context in general is the switchback to the object of perception and the possibility of reflection of the wider cultural contents through it. In that respect the object of architecture also possesses the value of the form able to communicate in the plane of projected architectural themes of the wider social context, those themes in which giving is made equal to opening, and exactly of opening of space. ${ }^{4}$ It is a matter of (post) production of sociability the main esthetic characteristic of which is mobility. 
In architecture the mentioned mobility can be apprehended in two ways: it can be part of the concept of universal dematerialization of the world but also the world of dematerialization itself. The parallels that can be drawn with the time of architectonic Avant-garde from the beginning of the $20^{\text {th }}$ century are significant as the document of the time in which the image of the future 'reflected' past was created. In that respect at the French philosophical line between Facillon and Baudrillard (Vie des formes vs. Formes de vie) $)^{5}$ we can project the genuineness of architecture manifestations ready to be the form and at the same time live it as a part of its, but also our reality.

\section{PROJECTION OF THE CASE}

Bearing in mind that architects develop their critique mechanism first of all through contradiction, ambiguity and paradox, albeit the fact that object of perception is most often 'seen' in its clear contours, it seems important within that context, to determine the role of the text. Since language is not the basic architectural means of expression let us start from the position from which the role of both the observer and the participant is defined at the same time. On this occasion we do not expect the design as a product, we are not in the position to renounce its apparatus. Insecurity even at the thought of actually doing so, can only be justified by the 'fear' of our inability to control the form of the expression, even though it does not concern the wish to avoid the mistakes or the ambition to achieve the effect greater than the necessary one. Undoubtedly, the contemporary world is presented in its fragmentariness and the questions of the form have equally become the questions of the time. If we undertake to pass the judgment on something, we have to take care of, as stated by Georg Lukacs (already in 1919) that criticism is contained, in all its sharpness and leaving no remnants, in the comprehension it originated from ${ }^{6}$, out of which we can draw a conclusion that the form of criticism due to the irony of the small life realities will in the end become the form of our questions.

And, also, according to John Berger each image incorporates the way of seeing. ${ }^{7}$ Besides helping us to accept the reality as a space of possibilities in which there is room for self-reliance of the generated statement, it, according to Lukacs, from the symbolic perception of life symbols allows us to form the reality, which becomes in our perception the comprehension of the world or the attitude to life. ${ }^{8}$

\section{PARTICULARLY UNIVERSAL}

Accepting that the theory of multiplicity can also be applied to architecture we accept that within architectural discourse a complex inter-connectedness 
of objects may be developed. Although philosophically cast both as a practical and contemplative ambient producing its buildings in reality, architecture, however, has no intention to answer all the questions at the same time. That means that architecture as a discipline possesses mechanisms by means of which it can control the difference between the real and its reality. According to Schelling's ${ }^{9}$ elaboration of the relationship between the infinite and final, which might have quite direct consequences for architecture, not resulting only in the analogy of such situation, in the final, there is a relative difference between the ideal and the real on which the possibility of the later rests. The reality of architecture lies in the illusion of the relative unity of the concept and the substance. Consequently, the necessary autonomy for existence in time is given to something concrete, namely real. It does not mean that the procedure is irreversible, at least not at the level of theoretical presumptions which could be in favor of the analytical characteristic of this procedure.

On the other side it is that multitude, which we are talking about, that 'conceals' within itself the versatility and unexpectedness which may become different or something else through the designed architecture. According to Jean Nouvel, it concerns the breakthrough $h^{10}$ the result of which is the change of perception from the category of material to immaterial, and so it becomes more than what we see. To formulate it otherwise, but in line with it, there is a position of another architect practitioner, Steven Holl, for whom the question of perception is inseparable from the very archetype experience of architecture in which the sensibilities take the central part. Holl associates such sensibility with quiet analysis. ${ }^{11}$ Positioning his deliberations within the field of phenomenology, even despite developing and making the analytical apparatus more complex for apprehending the experience of architecture, he proposes going much deeper into that which is behind the perceived. Although aware that directly in the layers behind there is an explanation of the intention, it seems more essential, for the case analysis, to perceive the existence of intention since that can bring us closer to the generative concept, namely to the creative part of the analysis, actually as per the nature of its procedure.

In the same philosophical register Pallasmaa develops the theoretical foundation for time fragmentation of the modern life which basically is the lack of concentration or non-development of mechanisms of perception, such as those required for apprehending the manifestation of architecture. This fragmentariness is on the other part associated with the necessity of stretching ${ }^{12}$ the notion of time which would enable the perception of the architectural space as another place of reality. It again concerns the intention which would create a time distance for development of the mental background of the future 
reminiscence required for acquiescence to the process of perception of spatial and time categories which architecture is still seen as.

\section{INTEGRITY}

In a direct dialogue On Some Singular Objects of Architecture, Baudrillard and Nouvel (the philosopher vs. the architect) demonstrate the relationship between the universal and the particular trying to define the positions on the parts of separate discourses, and of the common theme. The dialogue progresses at the trail of the concept by means of which the area of destabilization ${ }^{13}$ of architecture can precisely be formulated. In spite of rather general questions of the truth, illusion and reality, one can state that the very dialogue begins to assume the form of a discussion from the moment in which reality confronts the radical illusion, that is by means of seduction to which the collocutors agree by consensus. Its objective is not the answer to the question made, nor revelation of secrets, but identification of the loci in which it could (possibly) be found.

With Henry Bergson (Creative Evolution) such type of unpredictability was given a system role, and thus life is that reservoir of indeterminations necessary for freedom of development of multiple ways along which so many questions are asked..$^{14}$ In that indetermination there is a real time, namely duration, in which it is possible, according to Pallasmaa ${ }^{15}$ referring directly to Bergson, to see the construction of architecture as an integrated multitude of ways for spatial determination. However, the fact should not be disregarded that for Bergson freedom is a virtual category, whereas for architecture freedom represents a direct matter of selection. It seems that we slowly get transferred from the field of singularity to individuality, which even in spite of similarity in the sense that both notions are opposite to the notion of universal, changes the focus of perception from the object to the subject. To avoid being taken to a point of denying the very architectural form, individuality could be interpreted as the relation between the social spirit and the personal aspirations ${ }^{16}$, namely as a montage of the subjective projection.

\section{QUESTION OF SCALE}

Continuing with the exploration of the capacity of architecture in respect to the questions of its limitations and freedom, a whole set of notions is imposed which refer to the new minimalist circle in accordance with the modernism of the sixties. The essence of this analogy rests on reaffirmation of reduction and synthesis ${ }^{17}$ which results in the concept of the reduction of an object, 
which is in line with its selective perception, whereas synthesis is the other side of this mirror. In the past, the most direct relation with the object of perception, the truth as the identity between the thought and the object, was used for achieving simplicity ('less is more') by declaratively renouncing any ornament. Nowadays, that directness is the subject of reconsideration, more than simplicity of style or geometrized mature modernism, however not of the doubt which may result in melancholy or nostalgia for the past serenity and simplicity. ${ }^{18}$

According to Hal Foster we are witnesses, but not the stakeholders, of inflation of design in the perfect circle of production and consumption. ${ }^{19}$ This circle of the victim of semi-autonomy of architecture and the art belongs to design and its power of manipulation. It could be that very same perfect crime as mentioned by Neil Leach (Anesthetics of Architecture) after whom Architecture became a marginal synthetic task choosing between insensitive and radical anesthetization, finding itself in self-isolation. ${ }^{20}$

One of the most significant causes of such condition can be seen in twodimensionality of contemporary technological comfort of the artistic ambience, namely the lack of the true resistance of the substance to the development of industry and high technologies. Formerly defined by renouncing the ornaments, the present architecture as a style, sees the ornaments as non-structural element of the universal individuality dissolved by the process of dematerialization of the social reality. Nowadays the minimalist strategies of hierarchy of needs can be developed in relation to the real and virtual which would produce the space for eluding ${ }^{21}$, the distance from which one can also see that which no one has seen before. ${ }^{22}$

\section{IMAGE FRAME: ON/OFF}

Two-dimensionality of time is interpreted by Pallasmaa as an enforced weakness of the concept of materiality, ${ }^{23}$ whereas thinning of materials opens up a question of its structural linkages. It is true that by that its properties may be denied, but if first of all it concerns the procedure by means of which they are explored, it can take us further from which we have actually expected. It is natural that a man's knowledge of dematerialization is the one which forms the depth or simultaneity of the image combined from the memories and imagination. Besides Pallasmaa, Guliana Bruno also uses the classes of anatomy ${ }^{24}$ as a metaphor of plunging into the depths of perception. Pallasmaa's destroying of the very object by the subject introduces the act of intimacy, consequently to which closeness of perception occurs. On the other hand 
Bruno generates successive images in order to shape the event as a visible change of the condition. This is comprehensible since the starting points were also different. For phenomenology, the perception of an object is exhausted by understanding the position of the observer, more precisely his distance from it. At the same time the mental projection of the image of architecture on the form of film (central medium of modernism) emerges imperceptibly.

According to Rowe and Slatzky the question of transparency assumed the simultaneousness of perception of diverse spatial locations or coinciding of spatial time fixations. ${ }^{25}$ Duality of transparency was interpreted both through the image and touch, and the form, as an instrument for design. Ever since the time of Avant-garde the equivalent to the transparent form has been 'modernist' organization. However, nowadays functioning of the space is viewed more as the trust in the object of architecture and its ability to develop programs within the frames of contemporary polyvalent concepts. It still concerns the analysis against the freedom of manifestation of architecture in the reflections of the living reality.

In that respect it is important to take into consideration the concept of inhabiting the global culture of Nicolas Bourriaud. Not having departed from the concept of the form but opening up the questions of changeable socioeconomic conditions, he defines the operative realism ${ }^{26}$ as an instrument for positioning the subjective in relation to the objective, whereby the later, actually, represents the limits of reality. Transparency of the social circumstances and disappearance of the private within the public can in that way be reduced to its projection by avoiding, as regards architecture, overly complex contents of the circumstances which have brought it about. Visible transparency can be perceived as the consequence of the general dematerialization where the relations sufficient for the construction of Le Corbusier's 'plastic emotions' are visible.

\section{ABSTRACTION OF IDEAS}

According to Jeremy Till, the utopian character of the architectural fantasies is directly in contradiction with the spatial character of the architectural reality. Since the order projected by architecture as a vision of future cannot rest on the existing but on the reconstructed reality, the possibilities of such transformation have to be shaped contents of hope (form) built on security as much as on insecurity, not only in the process of its realization, but also in its very duration. ${ }^{27}$ Such vision could easily be transposed into mythological 

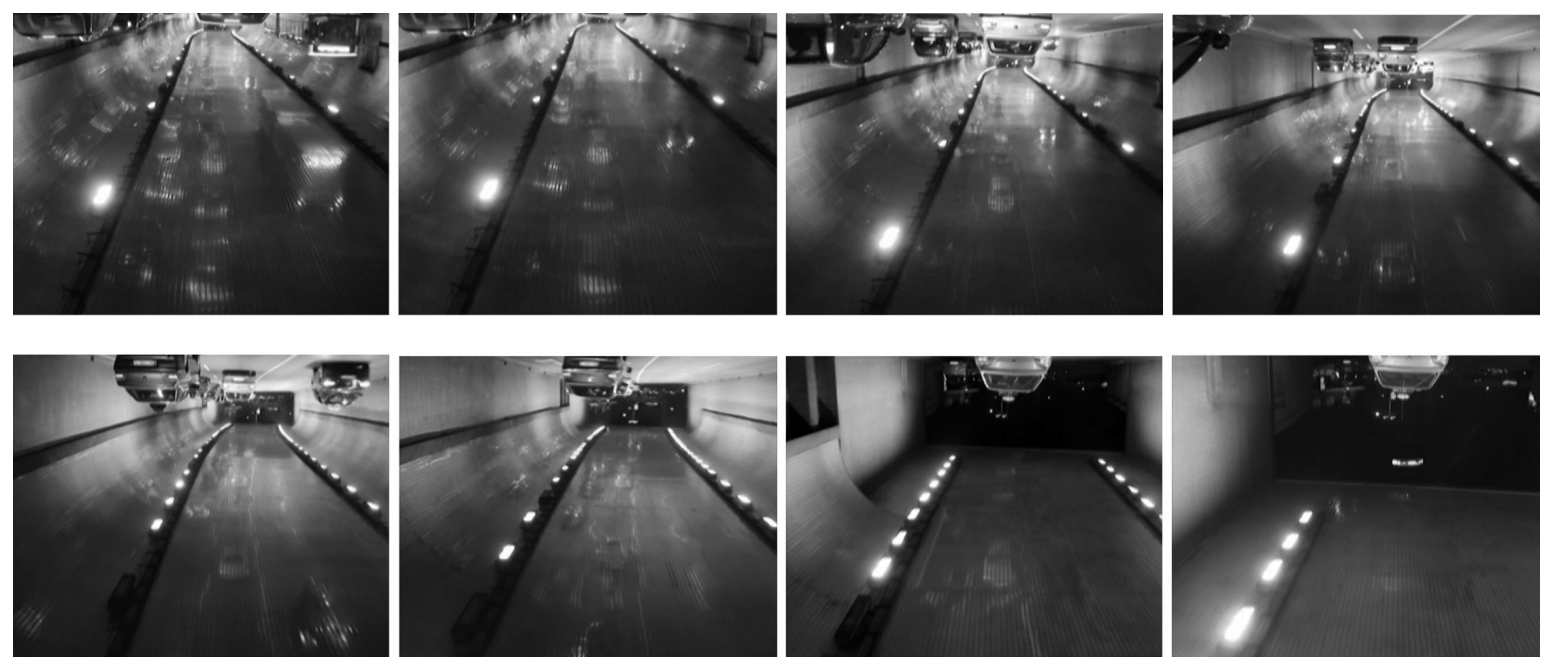

Sequence 1

Frames Crossover Video by Neo Arhitekti Beograd for Malta Design Week 2011 

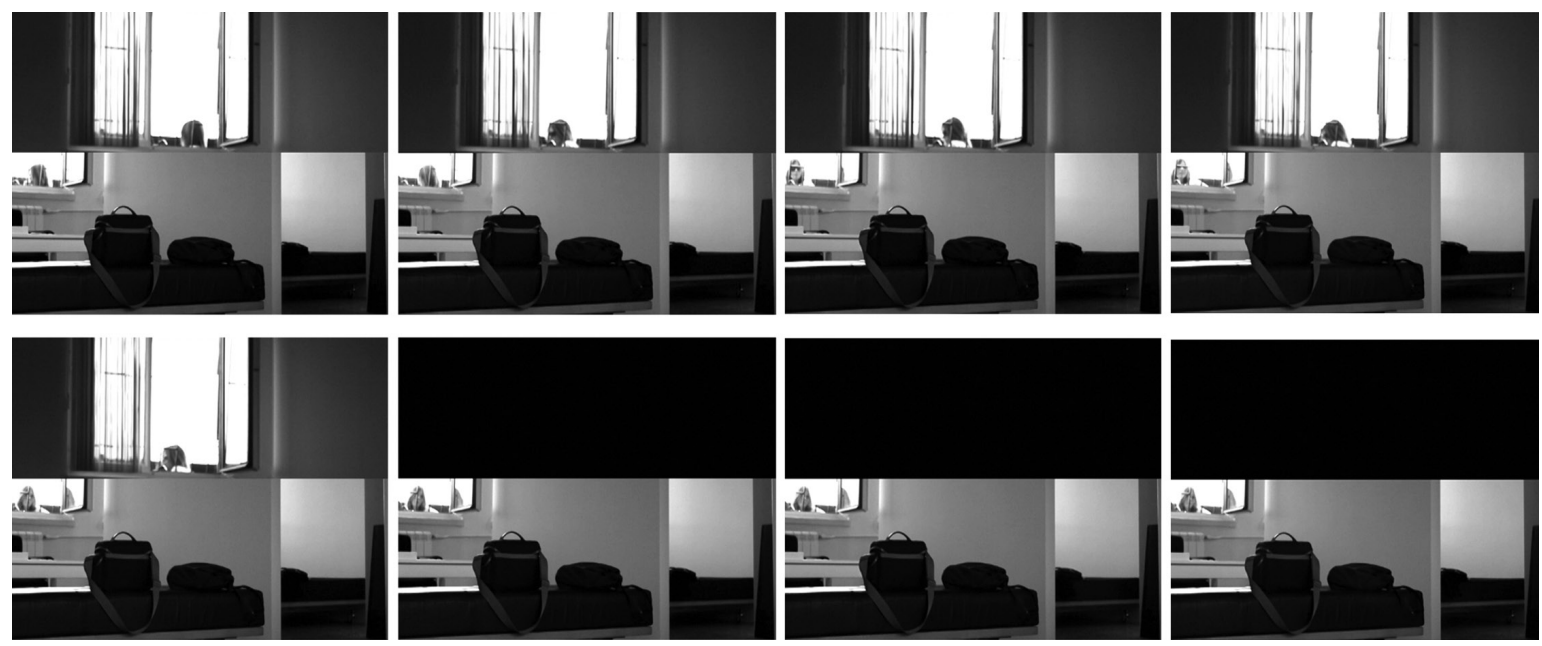

Sequence 2

Frames Crossover Video by Neo Arhitekti Beograd for Malta Design Week 2011 
character of architectural visions on infinity: the fixation mechanisms have the role of the instruments which 'treat' the reality of continuously projected ideas. However, the reflection of broader life visions as well as the role of fiction in the development of personality, or the control of the instincts, should be left aside. Images appearing in the foreground, according to Jean-Marie Schaeffer, are those able for transposition of imagination or satisfying the wishes ${ }^{28}$ aiming to achieve the possibility of their entering in the interaction with our real lives. ${ }^{29}$

According to Schaeffer (Why Fiction?), the fixation visions directly by their act of partial de-identification ${ }^{30}$ achieve the status of illusion, which in spite the fact that it concerns departing from ourselves, makes them part of our reality. In the projections which we use as architects, the world certainly exists in relation to our concept, however the establishment of the distance between the individual and the universal seems even more significant, which in the case of ideas represents the unexpectedly rigid link between the wish and possibilities. For this reason the aesthetic values of the ideas is actually purely functional, and its distance from the reality is on the bordering lines of the abstract image of the bright future of architecture.

\section{CTRL +}

The commitment of the contemporary architectural design to digitalization of reality is first of all a part of our image of it. Direct link between digital and virtual is achieved rather easily having in mind that presentation of architecture has always been based on visualization of real spatial circumstances. Verism which computer rendering aspires to is a logical continuation of the tendency that two-dimensionality of the image the world is changed by its threedimensional extension. However, since virtual is not real besides their rather direct mutual links and not always visible differences, the aspiration to more real produces the opposite proportional reality namely hyper-reality. The limits within which the methods of world modelization exist can easily be exceeded by formal potentials of generic design in which the role of the computer is not only unavoidable but rather significant. That would mean that self-deception is as much the result of non-control of the circumstances as it is of the impossibility of individual mechanisms of mobility in accordance with them.

\section{CUT ON TIME}

With the Avant-garde period of the early twentieth century the changeability as characteristic of the style has been established, and thereafter it was developed 
as the contents of the art doctrine with which the architectural framework of modernity was built. Today it gives an impression of an unreal in the absence of life which, like architecture itself, was on that occasion either in the take or in expectation. An entire century later within the same style frameworks the consideration of manifestation of architecture has to integrate the awareness of the every day freedom which has exceeded the limits of reality inhabiting the regions $^{31}$ of imaginary and illusive. For Detlef Mertins such style branching, which he names modernity unbound, ${ }^{32}$ is the result of preservation of the style flow which forced the modernity to depart from the autonomous spatial threedimensionality by introduction of time as an equal dimension. Futhermore the change was brought to the commonness of the visual impression ${ }^{33}$ in favor of its projected depth. For Bourriaud as well, to be modern ${ }^{34}$ today means to question the circumstances in which the present is presented in its most ephemeral and most unreal form, believing that each historical situation exists as a field of possibilities which happens only once. That means that priority has to be given to the moment $t^{35}$ over what was or what is yet to be. In that respect, the form of the present time and the present of the form are the result of the same case of projected circumstances, on one part, and the coincidence which operationalized the form itself as a concept, method, instrument or technique, on the other part. The intention which liberates the projection of architecture from the necessity to reflect in itself the ideas greater than the moment of reality itself, opens up the possibility of space and time for materialization of its line of moving, the line ever altered or uninterrupted. all aesthetic endeavors, and, if it contributes to the 'meaning', it is part of the characteritic of its independent nature, the nature visible equally clearly in abstraction as in the visual art." 
the paraphrase on the paraphrase of the title of the French authors, Henry Fossion and Nicolas Bourriaud, Vie des formes (1934) vs. Formes de vie (2002).

G. Lukač, Dusa i oblici (Beograd: Nolit, 1974), 44-45. On the Substance and Form of an Essay: to substantiate essay as the form, Lukacs states that even though the opinion is as per the contents, that which is important for its evaluation is not the judgment but the process of passing the judgment, and that it is a matter of a reflection which on one part rests on artistic gesture but on the other part differs from the art in all other aspects.

J. Berger, Ways of Seeing (London: Penguin Books,2008), 2. author's note, we see that which we view and we view that which we choose.

Lukač, Duša i oblici, 42.

F. W. J. Schelling, Bruno ili o božanskom i prirodnom principu stvari (Beograd: Fedon, 2008), 54-58, "Therefore, the laws of everything final can be in the universal form understood from the relative equality and contradiction of the final and infinite, which actually, where they exist, are called knowledge, but which are expressed in the objects the same as in the knowledge. All that, however, I am saying in general, and no wonder that someone, regardless individually, considers it insufficiently clear."

J. Boudrillard, J. Nouvel, The Singular Objects of Architecture (London/ Minneapolis: The University of Minnesota Press, 2002), 7. Illusion, Virtuality, Reality: between illusion and reality for Nouvel there is an attractive virtual space in which strategies of breakthrough develop: they force the perception to be transformed from material into immaterial, whereby "more than what we see" is read within the context of physical.

Steven Holl, Juhani Pallasmaa et all., Questions of perception - Phenomenology of Architecture (San Francisco/Japan: William Stout Publsihers/A=U, 2006), 40. Holl talking about the experience and sensibility talks about opening in the direction of perception which would enable accessibility of the inner world and enlightenment of its intensity; parallel to the question of perception there is also the question of intention

Ibid, 74. physical difference between the lived time and the time that lasts

Boudrillard and Nouvel, The Singular Objects of Architecture, 8.

A. Bergson, Stvaralacka evolucija (Sremski Karlovci/ Novi Sad: Izdavacka knjizarnica Zorana Stojanovica/ Dobra vest, 1991), 77.

Holl and Pallasmaa, Questions of perception, 74, refers to Bergson's concept on duration as multiplication of seccession, fusion and organization whereby architecture is given the role of some type of stage design, namely the frame for measuring the lived time expressed by "spatial resolution'

Boudrillard and Nouvel, The Singular Objects of Architecture, 55.

A. Zabalbeascoa and J. Rodriguez Marcos, minimalism (Barcelona: GG, 2000), 75.

Ibid., 135 .

H. Foster, Dizajn i zločin (Zagreb: VBZ, 2006), 28-29. "In contemporary design there is no such resistance: it enjoys in post-industrial technologies and happily sacrifices semi-autonomy of architecture and art to the manipulations of design", to determine in continuation "the lack of freedom" which Foster sees as the consequence of long past established relations of aesthetics and applicable from the time of Bauhaus, namely from the twenties of the last century.

N. Leach, The Anesthetics of Architecture (London: The MIT Press, 2000), 62-63. The Architecture of the Catwalk: in (overly)sharp criticism of the detachment of architecture from the social contents, Leach sees the architectural form as an abstract study 'in isolation' the contents of which are for the architects a well enough scientific and humanistic justification whereby design was entrusted with re-synthetization.

Zabalbeascoa and Marcos, minimalism, 9, minimalism is talked about as something that is usually understood as a "deliberate step backwards'.

Ibid., 119, as the consequence of disappearance of the void

Holl and Pallasmaa, Questions of perception, 31.

G. Bruno, Public intimacy: architecture and the visual arts (USA: MIT Press, 2007), 93. 
C. Rowe and R. Slatzky, Transparency (Basel/ Boston/ Berlin: Birkhauser - Verlag fur Architectur, 1997), 23.

Boudrillard and Nouvel, The Singular Objects of Architecture, the notions are mentioned such as: channels, soft and hard concepts, gaps, meandering, DJ-ing, VJ-ing, sampling.. moving in the direction of formal collectivism

J. Till, Architecture Depends (Cambridge- Massachusetts/ London- England: The MIT Press, 2009), 192. Hope against Hope, Formative Context: "This imagination, therefore, is not the imagination of the detached dreamer; it grows out of the real, fueled by very uncertainty that the rationalists and utopists found so threatening. It is an imaginative vision that both projects new futures and also embraces their imperfections."

Ž. M.Šefer, Zašto fikcija (Novi Sad: Svetovi, 2001), 332, problem of the fiction function has been reduced to three questions: status of mechanism, significance of function and its possible transcendentalism

Ibid., 331.

Ibid., 34.

Boudrillard and Nouvel, The Singular Objects of Architecture, 65/66, explaining that inhabiting the world is possible by means of images which help us experience the reality by activating in the fiction a great number of movements, not departing from it but on the contrary, experiencing it more intensively - oppositely placed use of form vs. use of world.

D. Mertins, Modernity Unboun (London: Architecture Words, AA, 2011)

Ibid., 70-72, in the text titled Transparency: Autonomy \& Reationality, Mertins analyses the question of perception of space in the time of Avant-garde, whereby even in spite of the visible artistic intention to make the relations in space "complicated' as per the profoundness, primarily the images, he believes that there also existed an intention to present the fourth dimension with an image as the manifestation of freedom of moving, of both the subject and the object of perception. J. Arnautović i Nikola Burio, in Figure u pokretu - savremena zapadna estetika, filozofija i teorija umetnosti, ed. M. Šuvaković i A. Erjavec (Beograd: Atoča, 2009), 750, “alter-modern’ as reaction to standardization, commercialization and globalized perception of contemporary society, and it concerns reconsideration of the individual and autonomous within the limits of the cultural landscape

Berger, John. Ways of Seeing.London: Penguin Books, 2008.

Bergson, Anri. Stvaralacka evolucija (H. Bergson, Creative Evolution). Sremski Karlovci/ Novi Sad: Izdavacka knjizarnica Zorana Stojanovica/ Dobra vest,1991.

Boudrillard, Jean and Jean Nouvel. The Singular Objects of Architecture. Minneapolis - London: The University of Minnesota Press, 2002.

Bourriaud, Nicolas. Postproduction. New York: Lukas \& Sternberg, 2002.

Bourriaud, Nicolas. Formes de vie - L'art moderne et l'invention de soi. France: Denoël, 2009

Foster, Hal. Dizajn i zločin - i druge polemike (Design and Crime - and other polemics). Zagreb: Hal, 2006.

Holl, Steven and Juhani Pallasmaa. Questions of perception - Phenomenology of Architecture. San Francisco/ Japan: William Stout Publsihers/ A=U, 2006.

Leach, Neil. The Anesthetics of Architecture. London: The MIT Press, 2000.

Lukač, Georg. Dusa i oblici (G. Lukacs, Soul and Form). Beograd: Nolit, 1974.

Maxwell, Robert. The Two Way Stretch - Modernism, Tradition and Innovation. London: Academy Editions, 1996.

Mertins, Detlef. Modernity Unbound. London: Architecture Words/ AA, 2011. 
Rowe, Colin and Robert Slatzky. Transparency. Basel/ Boston/ Berlin: Birkhauser - Verlag fur Architectur, 1997.

Scruton, Roger. The Aesthetics of Architecture. USA: Princeton University Press, 1979.

Šefer, Žan-Mari. Zašto fikcija? (J. M. Schaeffer, Pourquoi la fiction?). Novi Sad: Svetovi,2001.

Šuvaković, Miško i Aleš Erjavec. ed. Figure u pokretu - savremena zapadna estetika, filozofija $i$ teorija umetnosti. Beograd: Atoča, 2009.

Schelling, Friedrich Wilhelm Joseph .Bruno ili o božanskom i prirodnom principu stvari (Bruno, or On the Natural and the Divine Principle of Things).Beograd: Fedon, 2008.

Till, Jeremy. Architecture Depends. Cambridge- Massachusetts/ London- England: The MIT Press, 2009.

Zabalbeascoa, Anatxu and Javier Rodriguez Marcos. Minimalism. Barcelona: GG, 2000. 